Vol. 24, No. 3, Juli 2021, hlm. 456-465

p-ISSN: 1410-9344; e-ISSN: 2549-5631

WARTA LPM

homepage: http://journals.ums.ac.id/index.php/warta

\title{
Pemanfaatan Tanaman Obat Keluarga (TOGA) sebagai Alternatif Pengobatan Mandiri
}

\author{
Ismi Puspitasari, Ghani Nurfiana Fadma Sari, Ana Indrayati \\ Fakultas Farmasi Universitas Setia Budi Surakarta \\ Jl. Letjen Sutoyo Mojosongo Surakarta, 57127, Indonesia \\ Email: ismipuspitasari2508@gmail.com
}

\section{Article Info}

Submitted: 10 June 2020

Revised: 9 March 2021

Accepted: 31 May 2021

Published: 20 July 2021

Keywords: ESO, TOGA, herbal, arthritis

Kata kunci: ESO, TOGA, herbal, artritis

\section{Abstract}

TOGA (Family Medicinal Plant) is a type of medicinal plant which has medicinal properties, with easy maintenance and relatively low cost. TOGA is an alternative family medicine that is safe because it rarely causes side effects, is easily processed and consumed for first aid in cases of minor illnesses such as fever and cough, or helps maintain stamina. The existence of TOGA in the home environment is very important. The purpose of this service is to provide counseling about the use of TOGA as an alternative self-medication and to provide information about arthritis that can be treated using TOGA to the community RW 21 Nusukan. The method used in this service is to provide counseling, training and giving TOGA tree seedlings to be planted. The target partners are a group of housewives in RW 21, Nusukan, Banjarsari, Surakarta. The results of the development of activities in RW 21 can increase the motivation of housewives who come to better use the TOGA as a treatment, increase public knowledge about arthritis and natural materials that can be used to reduce arthritis pain.
Abstrak
TOGA (Tanaman Obat Keluarga) merupakan jenis tanaman pilihan yang berkhasiat sebagai obat dengan perawatan yang mudah dan biaya relatif murah. TOGA menjadi alternatif obat keluarga yang aman karena jarang menimbulkan efek samping, mudah diolah dan dikonsumsi untuk pertolongan pertama pada kasus penyakit ringan seperti demam, batuk, atau membantu menjaga stamina. Keberadaan TOGA di lingkungan rumah menjadi sangat penting. Tujuan dari pengabdian ini yaitu memberikan penyuluhan mengenai pemanfaatan TOGA sebagai alternatif pengobatan mandiri dan untuk memberikan informasi mengenai penyakit artritis yang dapat diobati menggunakan TOGA kepada masyarakat RW 21 Kelurahan Nusukan. Metode yang digunakan dalam pengabdian ini adalah dengan memberikan penyuluhan, pelatihan, serta pemberian bibit pohon TOGA untuk 
ditanam. Target mitra yaitu kelompok ibu-ibu rumah tangga di Wilayah RW 21 Kelurahan Nusukan, Banjarsari, Surakarta. Hasil pengembangan kegiatan di RW 21 dapat meningkatkan motivasi ibu-ibu rumah tangga yang datang untuk lebih memanfaatkan TOGA sebagai pengobatan, meningkatkan pengetahuan masyarakat mengenai artritis dan bahanbahan alamiah yang dapat digunakan untuk mengurangi nyeri artritis.

\section{PENDAHULUAN}

Tulang merupakan jaringan yang terkeras di dalam tubuh. Tulang-tulang tersebut antara satu dengan yang lain dihubungkan melalui persendian. Daerah persendian ini dapat mengalami kerusakan atau peradangan dan menimbulkan rasa sakit (nyeri). Penyakit yang menyerang persendian tersebut dikenal dengan nama "rematik" yang berasal dari bahasa Yunani yaitu rheumatismos. Selain persendian, penyakit ini dapat juga menyerang otot dan urat (Dalimartha 2006). Rematik atau disebut juga artritis merupakan istilah terminologi medis yang digunakan untuk menggambarkan segala kondisi sakit yang melibatkan sistem muskuloskeletal yaitu persendian, otot-otot, jaringan ikat, dan jaringan lunak di sekitar persendian dan tulang, yang diakibatkan oleh beberapa faktor diantaranya gangguan metabolik, faktor nutrisi, inflamasi, autoimun, trauma, dan penyebab idiopatik. Meskipun kelainan terjadi pada sendi, tulang, dan otot, penyakit artritis dapat pula mengenai jaringan ekstra-artikuler. Pada umumnya penyakit tersebut mempunyai bentuk-bentuk kelainan, di antaranya: a) hanya menyerang sendi dan otot; b) menyerang sendi, otot, dan alat-alat dalam tubuh lainnya; c) sistemik yang menghasilkan nyeri sendi; dan d) jaringan ikat yang menyebar (difus) yang menyerang sistem sendi, otot, kulit, dan alat-alat dalam (Syafei 2010).

Artritis atau penyakit rematik atau muskoskeletal adalah penyakit yang ditandai oleh nyeri, pembengkakan dan kekakuan pada persendian. Saat ini terdapat lebih dari 200 jenis penyakit persendian diantaranya adalah ostheoartritis, rheumatoid artritis (RA), lupus, ankylosing spondylitis (AS), psoriatic arthritis (PsA), Sjogren's syndrome, gout, scleroderma, infectious arthritis, juvenile idiopathic arthritis dan polymyalgia rheumatica. American College of Rheumatology melaporkan bahwa pada tahun
2013, penyakit rematik menyerang sekitar 7 juta warga di Amerika, 300 ribu diantaranya adalah anak-anak. Prevalensi reumatik pada wanita lebih tinggi dibandingkan pria dengan perbandingan pada wanita (1:12) dan pria (1:20). RA merupakan jenis rematik paling umum yang disebabkan oleh penyakit autoimun, yaitu penyakit yang terjadi karena sistem imun menyerang sel-sel tubuh, jaringan dan organ sendiri.

RA merupakan penyakit kronis yang menyebabkan nyeri sendi, kekakuan, pembengkakan dan penurunan pergerakan pada persendian. RA menyebabkan gangguan organ tubuh lain seperti mata, kulit atau paruparu. Kekakun sendi pada pasien RA seringkali memburuk pada waktu pagi satu hingga dua jam atau bahkan akan terjadi sepanjang hari. Jenis artritis kedua adalah osteoartritis yaitu penyakit persendian yang terjadi karena adanya kerusakan tulang rawan (bantalan tulang). Kerusakan ini menyebabkan pergesekan antar tulang yang lama kelamaan menimbulkan peradangan pada sendi. Osteoartritis disebabkan oleh banyak faktor diantaranya adalah faktor genetik, usia, menopause, obesitas, cidera pada persendian, aktivitas fisik yang menyebabkan beban pada persendian meningkat dan lainlain. Lupus seperti halnya RA merupakan penyakit yang disebabkan oleh autoimun. Lupus mempengaruhi bagian tubuh yang lain seperti sendi, kulit, ginjal, sel-sel darah, otak, jantung, dan pari-paru. Gejala lupus mirip dengan penyakit persendian yang lain, yang membedakannya adalah munculnya ruam pada wajah, memanjang dari tulang hidung, pipi kanan kiri, tulang rahang sehingga membentuk gambaran seperti kupu-kupu. Jenis ruam pada lupus dikenal dengan butterfly rush. Lupus disebabkan oleh faktor genetik dan lingkungan diantaranya adalah paparan sinar matahari, infeksi, konsumsi obat-obatan tertentu seperti 
obat penurun tekanan darah tinggi, obat sakit kepala, dan antibiotik.

Sjogren's syndrome merupakan komplikasi dari penyakit autoimun seperti RA dan osteoartritis. Sel-sel sistem imun tubuh menyerang kelenjar penghasil air mata dan saliva sehingga menyebabkan mata dan mulut kering. Pasien Sjogren's syndrome nampak seperti orang sehat namun sangat beresiko mengalami kanker kelenjar limfe (lymphoma). Gout merupakan penyakit persendian yang umum dan komplek. Gout ditandai oleh timbulnya rasa nyeri pada persendian terutama pada bagian bawah ibu jari kaki. Rasa nyeri seperti terbakar umumnya muncul secara tiba-tiba. Gout terjadi karena penumpukan kristal asam urat pada persendian. Asam urat berasal dari pemecahan purin, suatu asam amino yang banyak terdapat pada makanan-makanan tertentu seperti jeroan (hati, ginjal, dan otak), makanan laut, daging, dan lain-lain. Selain makanan, beberapa minuman merupakan sumber purin seperti minumal beralkohol dan minuman dengan pemanis fruktosa dalam jumlah tinggi. Secara normal, asam urat akan larut di dalam darah, kemudian masuk ke dalam ginjal dan dikeluarkan melalui urin. Kadar asam urat yang tinggi menyebabkan penumpukan pada persendian membentuk kristal yang dapat memicu terjadinya gout yang ditandai oleh nyeri, bengkak, dan radang.

Secara garis besar, artritis dibagi menjadi dua golongan yaitu golongan artritis artikuler (artritis sendi) dan golongan artritis ekstra artikuler/non-artikuler (artritis yang menyerang jaringan lunak di luar sendi) (Dalimartha, 2006). Artritis rematoid termasuk golongan artritis artikuler dan merupakan penyakit autoimun yang disebabkan karena adanya peradangan atau inflamasi yang dapat menyebabkan kerusakan sendi dan nyeri. Nyeri dapat muncul apabila adanya suatu rangsangan yang mengenai reseptor nyeri. Penyebab artritis rematoid belum diketahui secara pasti, biasanya merupakan kombinasi dari faktor genetik, lingkungan, hormonal, dan faktor sistem reproduksi. Faktor pencetus terbesar adalah infeksi bakteri, mikoplasma, dan virus (Yuliati, et al., 2013). Penderita artritis rematoid pada lansia diseluruh dunia telah mencapai angka 355 juta jiwa, artinya 1 dari 6 lansia di dunia menderita reumatik. Angka ini diperkirakan akan terus meningkat hingga tahun 2025 dengan indikasi lebih dari 25\% akan mengalami kelumpuhan. Organisasi kesehatan dunia (WHO) melaporkan bahwa $20 \%$ penduduk dunia terserang penyakit artritis rematoid, di mana 5-10\% adalah mereka yang berusia 5-20 tahun dan 20\% dari mereka yang berusia 55 tahun (WHO, 2012).

Tingginya prevalensi penyakit artritis akan menimbulkan implikasi peningkatan biaya kesehatan, baik biaya pengobatan, tindakan penunjang medis yang lain, maupun biaya akibat penurunan produktivitas kerja. Permasalahan lain yang timbul adalah adanya efek samping dari pemakaian obat-obat artritis. Efek samping obat (ESO) adalah reaksi obat yang tidak dikehendaki yang terjadi pada dosis terapi. Masalah ESO sering terjadi pada pengobatan konvensional menggunakan obat-obat sintetis untuk menangani penyakit seperti artritis. Obat pilihan pertama untuk terapi artritis non-gout adalah analgesik oral (paracetamol dan tramadol) dan golongan anti-inflamasi nonsteroid (AINS) seperti asetosal, diklofenak, ibuprofen, dan lain-lain. Sedangkan untuk terapi penyakit gout atau asam urat diberi alopurinol sebagai obat anti asam urat. Semua obat tersebut harus dikonsumsi oleh pasien artritis dalam jangka waktu yang lama. Hal ini menyebabkan risiko terjadinya efek samping obat menjadi tinggi (Dipiro et al, 2017).

Risiko efek samping tersebut dapat memicu ketidakpatuhan pasien dalam mengkonsumsi obat sehingga tujuan terapi artritis berupa menekan gejala-gejala, mengurangi kehilangan fungsi sendi, dan memperlambat proses destruktif atau kerusakan sendi tidak tercapai dan kondisi penyakit akan semakin memburuk. Hal ini memicu usaha pencarian obat yang lebih efektif dan aman. Salah satu alternatif yang dapat digunakan untuk terapi artritis adalah obat dari tanaman herbal (Long et al 2001). Selain itu, pengobatan artritis menggunakan obat anti-inflamasi golongan kortikosteroid dan non steroid (AINS) sering menimbulkan efek samping pada saluran cerna yang dapat memicu tukak lambung (Tjay \& Rahardja, 2007). Masalah ESO ditemukan pada beberapa penyakit lainnya, sehingga banyak orang mulai beralih ke pengobatan tradisional (back to nature). 
Tumbuh-tumbuhan telah menjadi sumber penting sebagai pengobatan sejak ribuan tahun yang lalu. Penggunaan tumbuh-tumbuhan untuk penyembuhan merupakan bentuk pengobatan tertua di dunia. Setiap budaya di dunia memiliki sistem pengobatan tradisional yang khas dan di setiap daerah dijumpai berbagai macam jenis tumbuhan yang dapat dimanfaatkan sebagai obat. Sejarah awal mengapa tumbuhan digunakan sebagai obat sulit untuk ditelusuri, namun demikian ada pendapat bahwa suatu tumbuhan digunakan sebagai obat didasarkan pada tanda-tanda fisik (bentuk, warna, dan rasa) yang ada pada tumbuhan atau ada pada bagian tumbuhan tersebut, dan tanda-tanda tersebut diyakini berkaitan dengan tandatanda penyebab penyakit yang akan diobatinya (Ronald, 2006). Obat tradisional adalah obat jadi atau ramuan bahan alam yang berasal dari tumbuhan, hewan, mineral, sediaan galenik atau campuran bahan-bahan tersebut yang secara tradisional telah digunakan untuk pengobatan berdasarkan pengalaman. Pada kenyataannya bahan obat alam yang berasal dari tumbuhan porsinya lebih besar dibandingkan yang berasal dari hewan atau mineral, sehingga sebutan Obat Tradisional (OT) hampir selalu identik dengan Tumbuhan Obat (TO) karena sebagian besar OT berasal dari TO.

Beberapa tanaman herbal yang berkhasiat untuk mengurangi nyeri yang disebabkan oleh artritis yaitu jahe, tyme (mint), bawang putih, teh hijau, kayu manis, lada hitam, willow bark, lidah buaya, temulawak, kunyit, brotowali, lidah buaya, jahe merah, dan lain-lain. Tanamantanaman tersebut berdasarkan penelitian mempunyai khasiat sebagai anti inflamasi atau anti radang (Afifah dan Lentera, 2003). Bahkan jahe merah sendiri sudah dilakukan uji klinis dan terbukti efektif dalam mengurangi nyeri otot, rasa kaku, dan kesulitan menggerakkan lutut pada pasien yang mengalami osteoartritis dengan efek samping yang kecil. Oleh karena itu, ekstrak jahe merah direkomendasikan sebagai obat yang aman untuk meringankan gejala pada pasien tersebut. Uji klinis ini menggunakan kapsul zintoma yang mengandung $250 \mathrm{mg}$ serbuk rimpang jahe merah dengan pemberian dua kali sehari selama 6 minggu secara oral pada pasien osteoartritis (Zakeri et al, 2011) .
Menurut Rahayu et al., (2006), salah satu ciri budaya masyarakat di negara berkembang adalah masih dominannya unsur-unsur tradisional dalam kehidupan sehari-hari. Keadaan ini didukung oleh keanekaragaman hayati yang terhimpun dalam berbagai tipe ekosistem yang pemanfaatannya telah mengalami sejarah panjang sebagai bagian dari kebudayaan. Salah satu aktivitas tersebut adalah penggunaan tumbuhan obat sebagai bahan obat oleh berbagai suku bangsa atau sekelompok masyarakat yang tinggal di pedalaman, bahkan dalam satuan terkecil di masyarakat, yaitu keluarga.

TOGA adalah tanaman obat keluarga, yang dahulu disebut sebagai "Apotik Hidup". TOGA merupakan beberapa jenis tanaman obat pilihan yang dapat ditanam di pekarangan rumah atau lingkungan rumah. Tanaman obat yang dipilih biasanya tanaman yang dapat dipergunakan untuk pertolongan pertama untuk penyakit ringan seperti demam dan batuk. Keberadaan tanaman obat di lingkungan rumah sangat penting, terutama bagi keluarga yang tidak memiliki akses mudah ke pelayanan medis seperti klinik, puskesmas ataupun rumah sakit. TOGA dapat dibudidayakan dalam pot-pot atau di lahan sekitar rumah dalam skala kecil dan menengah, yang selanjutnya dapat disalurkan kepada masyarakat untuk menunjang peningkatan kesehatan masyarakat, dan sekaligus dapat menjadi tambahan pendapatan keluarga. Kondisi alam Indonesia memungkinkan banyak jenis tanaman obat yang berguna bagi kesehatan dapat tumbuh subur di berbagai wilayahnya.

Jenis tanaman yang dapat dibudidayakan untuk tanaman obat keluarga adalah jenisjenis tanaman yang memenuhi kriteria seperti: disebutkan dalam buku pemanfaatan tanaman obat, lazim digunakan sebagai obat di daerah permukiman, tumbuh dan hidup dengan baik di daerah permukiman, dapat dimanfaatkan untuk keperluan lain, misalnya: buah-buahan, dan bumbu masak, jenis tanaman yang hampir punah, dan jenis tanaman yang masih liar (Tukiman, 2004).

Penanaman tanaman obat di pekarangan selain untuk obat, juga dapat ditata dengan baik sebagai penghias pekarangan. Pekarangan 
rumah akan menjadi tampak asri dan penghuninya juga dapat memperoleh obatobatan yang diperlukan untuk menjaga kesehatan (Muhlisah, 2000). Tanaman obat yang sering ditanam di pekarangan adalah: sirih, kunyit, jahe, temulawak, kembang sepatu, daun dewa, sambiloto, beluntas, jambu biji, belimbing wuluh, bunga kenop, cengkeh, delima, jeruk nipis, kumis kucing, manggis, dan tomat. Pemanfaatan TOGA umumnya untuk pengobatan gangguan kesehatan keluarga menurut gejalagejala umum seperti demam, panas, batuk, sakit perut, dan gatal-gatal (Ridwan, 2007). Pada saat anggota keluarga ada yang sakit, TOGA dapat dijadikan sebagai alternatif obat tradisional yang paling mudah dicari, murah serta memiliki efek samping yang jauh lebih rendah dibandingkan obat-obatan kimia (Muhlisah, 2000). Dengan memahami manfaat, khasiat dan jenis tanaman tertentu, tanaman obat menjadi pilihan keluarga dalam memilih obat alami yang aman.

Manfaat lain dari TOGA selain untuk pengobatan adalah: (1) penambah gizi keluarga (pepaya, timun, dan bayam), (2) bumbu atau rempah-rempah masakan (kunyit, kencur, jahe, serai, dan daun salam), dan (3) menambah keindahan (mawar, melati, bunga matahari, kembang sepatu, tapak dara, dan kumis kucing) (Savitri, 2016).Tradisi pengobatan menggunakan tanaman obat ini tidak terlepas dari kaitan budaya setempat. Persepsi mengenai konsep sakit, sehat, dan keragaman jenis tumbuhan yang digunakan sebagai obat tradisional terbentuk melalui proses sosialisasi yang secara turuntemurun dipercaya dan diyakini kebenarannya.

Perhatian dunia dalam dua dasawarsa terakhir terhadap obat-obatan dari bahan alam (tanaman obat) juga menunjukkan peningkatan. Indonesia menjadi salah satu negara yang sangat berpotensi dalam mengembangkan budidaya tanaman obat dan memanfaatkannya sebagai alternatif pengobatan. Hal ini dikarenakan Indonesia kaya akan sumber daya alam dengan keanekaragaman hayati yang tinggi. Salah satu wilayah di Indonesia yang berpotensi untuk mengembangkan budidaya tanaman obat adalah wilayah Surakarta khususnya di RW 21, Kelurahan Nusukan, Kecamatan Banjarsari. Masyarakat di wilayah tersebut masih memiliki lahan pekarangan yang cukup luas, sehingga pemanfaatan dan pengelolaan lingkungan dapat dioptimalkan dengan penanaman TOGA. Minat masyarakat di daerah tersebut akan obat herbal atau jamu tradisional juga sangat tinggi sehingga sangat perlu untuk menggali potensipotensi tanaman obat yang belum dikenal oleh masyarakat agar lebih memahami tentang berbagai manfaat dari obat herbal.

Berdasarkan observasi di lapangan diketahui bahwa beberapa ibu rumah tangga telah menanam TOGA, namun demikian jumlah TOGA yang ditanam jumlahnya terbatas. Sebagian dari mereka telah mengetahui khasiat TOGA dan secara teknis juga telah mampu mengolah TOGA, namun demikian mereka belum memahami khasiat TOGA secara ilmiah. Oleh karena itu perlu dilakukan penyuluhan tentang khasiat TOGA secara ilmiah. Masyarakat yang telah memiliki pengetahuan tentang khasiat TOGA dan menguasai cara pengolahannya dapat membudidayakan tanaman obat secara individual dan memanfaatkannya sehingga akan terwujud prinsip kemandirian dalam pengobatan keluarga. Selain itu TOGA juga dapat dikembangkan menjadi usaha kecil dan menengah di bidang obat-obatan herbal yang selanjutnya dapat disalurkan ke masyarakat. Dengan demikian, masyarakat tidak hanya dituntut untuk mengetahui penanaman dan pemanfaatan tanaman obat saja, tetapi juga harus mengetahui bagaimana cara mengolah tanaman obat yang baik (Supriyanto, 2006).

Beberapa faktor yang memungkinkan terjadinya pengolahan tanaman obat yang kurang baik, antara lain: minimnya pengetahuan masyarakat, terbatasnya buku atau sumber literatur yang dimiliki masyarakat, serta kurangnya sosialisasi dari pemerintah dan instansi terkait tentang pengolahan tanaman obat beserta manfaatnya. Beberapa cara mengolah tanaman obat, antara lain (1) memeras; bahan yang digunakan adalah bahan yang masih segar. Bahan tersebut dihaluskan dengan ditambahkan sedikit air kemudian diperas hingga $1 / 4$ cangkir. Jika kurang, air matang ditambahkan pada ampas kemudian diperas lagi, (2) merebus; tanaman obat direbus agar zat-zat yang berkhasiat dalam tanaman larut ke dalam air (air bersih). Pada awal perebusan digunakan api besar hingga mendidih, setelah mendidih api 
dikecilkan dan dibiarkan selama kurang lebih 5 menit, dan (3) menyeduh; bahan yang telah diramu diseduh dengan air panas dan dididihkan selama kurang lebih lima menit kemudian hasil seduhan disaring (Anonim, 2005).

Hal-hal yang harus diperhatikan dalam pengolahan tanaman obat antara lain adalah: (1) bahan tanaman; bahan tanaman yang digunakan untuk obat harus dalam keadaan segar. Jika digunakan bahan tanaman yang kering, maka keadaan bahan harus baik. Bahan tanaman dicuci terlebih dahulu dengan air sampai bersih sebelum digunakan. Persyaratan tersebut tidak berlaku untukramuan yang dicampur minyak dan ramuan bercampur bahan kering, seperti serbuk atau pil, (2) peralatan yang digunakan; peralatan yang akan dipakai, seperti sendok, gelas, panci perebusan, saringan, botol, atau yang lain dibersihkan terlebih dahulu. Begitupula setelah digunakan, alat harus dibersihkan lagi karena adanya residu pada alat dapat mendatangkan kuman penyakit, (3) air; air yang digunakan adalah air masak dan bersih, kecuali jika ramuan obat harus direbus terlebih dahulu maka dapat digunakan air mentah yang bersih, (4) jangka waktu pemakaian; mengingat kebanyakan ramuan obat tradisional dibuat dengan cara direbus, diperas, atau dimakan mentah, maka jika ramuan obat dibuat dengan direbus maka hanya boleh disimpan sehari atau 24 jam dan jika ramuan obat dibuat dengan perasan tanpa direbus, hanya boleh disimpan selama 12 jam. Setelah jangka waktu tersebut, sebaiknya ramuan obat dibuang dan dibuat lagi yang baru jika memerlukannya, dan (5) tindakan medis lainnya; meskipun pemakaian obat tradisional dianjurkan sebagai tindakan pengobatan penyakit, maka tidak berarti pengobatan medis atau dokter diabaikan, sehingga jika penderita penyakitnya parah dapat dibawa ke rumah sakit/ puskesmas/dokter terdekat (Muhlisah, 2000).

Selain memberikan pengenalan dan
pemahaman mengenai tanaman obat, permasalahan lain dari mitra adalah kurangnya informasi dan penerapan penanaman tanaman obat di lingkup keluarga. Sejauh ini, pelaksanaan penanaman dan pemanfaatan tanaman obat dilakukan di satu lokasi umum atau pada kegiatan tertentu seperti saat kerja bakti. Namun di area halaman rumah tiap keluarga masih jarang dijumpai, lebih dominan tanaman-tanaman hias, dan sekalipun ditiap rumah memiliki TOGA. Mitra kurang memahami cara memberikan pengobatan mandiri kepada keluarga menggunakan TOGA ataupun menetapkan suatu jenis tanaman untuk pengobatan artritis yang cukup banyak diderita oleh masyarakat setempat. Dengan demikian, TOGA yang sudah ada kurang dimanfaatkan secara optimal. Sasaran dari program pengabdian kepada masyarakat ini adalah ibu-ibu PKK yaitu suatu perkumpulan dari para ibu yang berasal dari tiap keluarga yang ada di wilayah RW 21, Nusukan, Banjarsari. Peran para ibu dalam tiap keluarga sangat penting, terkhususnya dalam hal penanaman, pelestarian dan pemanfaatan TOGA sebagai obat keluarga.

Solusi yang akan diberikan berdasarkan permasalahan yang ada di Desa Bibis Luhur RW 21, adalah: memberikan penyuluhan tentang khasiat TOGA, memberikan pelatihan cara penanaman dan cara pengolahan TOGA, memberikan penyuluhan tentang penyakit artritis, efek yang ditimbulkan dan pengobatan herbal untuk artritis yang termasuk kategori TOGA, memberikan krim anti nyeri untuk artritis dengan bahan aktif dari TOGA.

Tujuan dilaksanakannya kegiatan pengabdian masyarakat adalah untuk meningkatkan pengetahuan tentang khasiat TOGA secara ilmiah pada ibu-ibu PKK di Desa Bibis Luhur RW 21 Nusukan Surakarta, meningkatkan pengetahuan tentang tata cara menanam TOGA pada ibu-ibu PKK di Desa Bibis Luhur RW 21 Nusukan Surakarta, meningkatkan keterampilan untuk mengolah TOGA pada ibuibu PKK di Desa Bibis Luhur RW 21 Nusukan Surakarta., dan meningkatkan pengetahuan tentang penyakit artritis dan tanaman herbal yang berkhasiat untuk artritis pada ibu-ibu PKK di Desa Bibis Luhur RW 21 Nusukan Surakarta.

\section{METODE}

Sasaran kegiatan pengabdian ini adalah ibuibu PKK di Desa Bibis Luhur, Kelurahan Nusukan, Kota Surakarta. Target sasaran berjumlah 30 orang. Kegiatan ini dilakukan pada tanggal 27 November 2019 dan 13 Desember 2019 yang bertepatan pada perkumpulan ibu-ibu PKK RW 21 Nusukan. 
Metode kegiatan yang dilakukan adalah, (1) Ceramah, metode ceramah yang dikombinasikan dengan membagikan leaflet yang digunakan untuk menyampaikan materi tentang: khasiat TOGA secara ilmiah, penanaman TOGA, dan pengolahan TOGA. Penggunaan metode ini dapat memberikan materi relatif banyak secara padat, cepat, dan mudah, (2) demonstrasi, metode demonstrasi digunakan untuk menunjukkan suatu proses kerja sehingga memberikan kemudahan bagi peserta pengabdian. Demonstrasi dilakukan oleh tim pengabdian sebagai narasumber untuk menyampaikan atau mempraktikkan penanaman TOGA yang benar.

Langkah-langkah kegiatan meliputi:

a. Persiapan, merupakan perencanaan program pengabdian yang meliputi: koordinasi dengan pihak desa lokasi pengabdian, penetapan waktu pelatihan, penentuan sasaran dan target peserta pelatihan, dan perencanaan materi pelatihan.

b. Pelaksanaan, untuk meningkatkan pengetahuan ibu rumah tangga tentang penyakit artritis, khasiat TOGA secara ilmiah dan tata cara menanam TOGA serta meningkatkan keterampilan dalam mengolah TOGA diberikan kegiatan pelatihan. Pelatihan dilakukan oleh tim pengabdian untuk penyamaan persepsi dengan peserta. Pelatihan dilakukan dengan penyediaan sarana dan prasarana kegiatan pengabdian dalam upaya peningkatan pengetahuan dan keterampilan ibu rumah tangga, meliputi penyampaian makalah tentang jenis tanaman obat-obatan dan khasiatnya, serta praktik cara penanaman tanaman obat yang baik

c. Pembagian bibit TOGA yang berkhasiat anti-artritis, pembagian bibit ini dilakukan untuk merealisasikan pemanfaatan TOGA di lingkup keluarga, maka dilakukan pembagian bibit TOGA dan pemantauan/ follow-up terkait realisasi pemanfaatan TOGA. Diharapkan dengan adanya kegiatan ini, minat masyarakat semakin meningkat untuk menggunakan TOGA sebagai alternatif pengobatan.

\section{HASIL DAN PEMBAHASAN}

Kegiatan pengabdian masyarakat ini dilakukan dengan 5 tahap, yaitu: tahap observasi dan koordinasi, penyuluhan penyakit artritis dan TOGA, pelatihan penanaman bibit TOGA, penyerahan bibit TOGA dan krim anti nyeri untuk artritis, dan tahap evaluasi. Tahap observasi dan koordinasi dengan pejabat setempat di Kelurahan Nusukan merupakan tahap awal yang bertujuan untuk mengetahui permasalahan yang dihadapi oleh ibu-ibu PKK

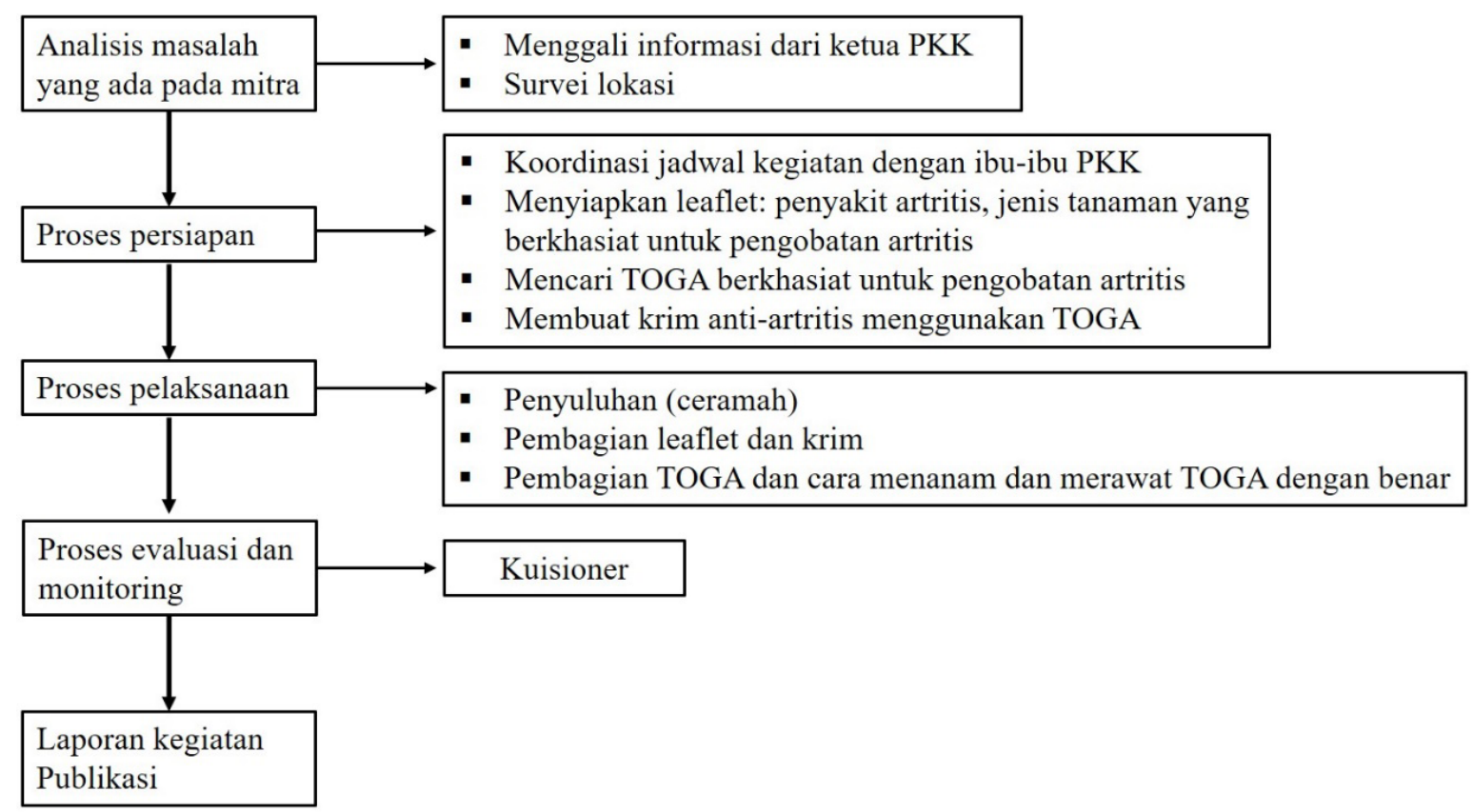

Alur Kegiatan Pengabdian Masyarakat 
RW 21 Kelurahan Nusukan dan koordinasi membahas solusi dan program pengabdian yang akan dilaksanakan serta waktu pelaksanaan kegiatan. Keberhasilan target jumlah peserta pengabdian dapat dikatakan sangat baik, dari 30 orang peserta yang diundang, semuanya (100\%) dapat menghadiri kegiatan penyuluhan dan pelatihan budidaya TOGA.

Tahap kedua berupa penyuluhan mengenai penyakit artritis, penyebab terjadinya penyakit artritis, dampak jika terkena artritis pada tubuh dan solusi yang dapat dilakukan untuk mengobati artritis. Tujuan dari penyuluhan ini adalah memberikan informasi mendetail mengenai penyakit artritis. Antusisme ibuibu PKK cukup tinggi yang ditandai dengan banyaknya pertanyaan selama sesi penyuluhan. Pada tahap penyuluhan ini diberikan juga materi dalam bentuk leafleat yang dibagikan kepada ibu-ibu PKK. Berdasarkan hasil penyampaian materi penyuluhan tentang penyakit artritis, tanaman herbal yang berkhasiat untuk artritis, dan khasiat TOGA dapat meningkatkan pengetahuan ibu-ibu PKK RW 21 Nusukan yang terlihat dari antusias ibu-ibu dalam menjawab pertanyaan setelah materi tersampaikan.

Tahap ketiga berupa pelatihan penanaman bibit TOGA yang dilakukan dengan cara mendemostrasikan penanaman TOGA di dalam pot secara langsung sehingga dapat dipraktikkan oleh masyarakat. Peserta dilatih untuk dapat melakukan kegiatan penanaman bibit TOGA secara mendiri. Setelah pelatihan penanaman bibit TOGA, tim abdimas membagikan bibitbibit tanaman herbal kepada masyarakat RW 21, sehingga nantinya bisa secara langsung dipraktikkan oleh ibu-ibu PKK. Antusiasme peserta cukup tinggi pada tahap kegiatan ini ditandai dengan banyaknya pertanyaan dan keikutsertaan ibu-ibu PKK dalam pelatihan penanaman bibit Toga.
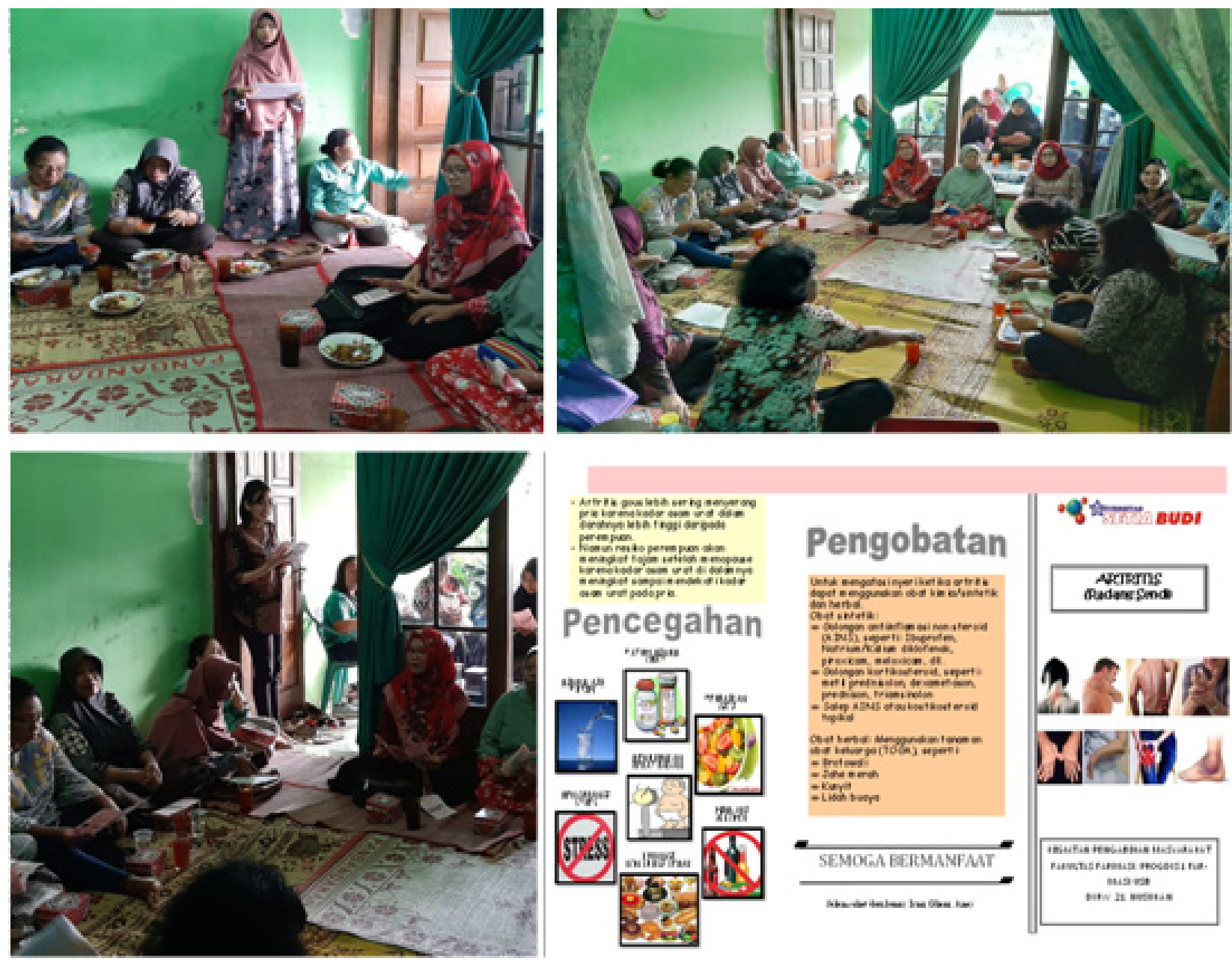

Gambar 1. Kegiatan Penyuluhan TOGA dan Penyakit Artritis 
Tahap keempat berupa penyerahan bibit toga yang dilakukan setelah dilaksanakannya pelatihan penanaman bibit toga pada pot. Pada kegiatan ini dilakukan penyerahan bibit TOGA pot, media tanam dan krim yang bahan aktifnya dari tanaman herbal yang berkhasiat sebagai anti nyeri untuk artritis. Bantuan bibit toga tersebut sejumlah 70 pohon yang terdiri dari bibit temulawak, kunyit, lidah buaya, brotowali, dan jahe merah yang akan di bagikan ke setiap perwakilan RT pada RW 21 Kelurahan Nusukan. Masyarakat merespon dengan baik diadakannya kegiatan ini, selain mendapatkan tambahan ilmu pengetahuan masyarakat juga dapat meningkatkan ketrampilan tentang budidaya TOGA. Masyarakat juga berpesan kepada tim pengabdian untuk terus dilakukannya kegiatankegiatan yang menunjang kualitas hidup mereka dan meningkatkan keterampilan diri pada masyarakat RW 21 Nusukan Surakarta.
Tahap terakhir yang dilaksanakan adalah evaluasi dan monitoring. Kegiatan ini dilaksanakan dengan memberikan kuesioner pada ibu-ibu PKK yang bertindak sebagai peserta untuk memberikan jawaban kepuasan dan manfaat dilakukannya kegiatan pengabdian. Hasil kuesioner menunjukkan tingkat respon kepuasan yang tinggi oleh ibu-ibu PKK terhadap kegiatan yang telah dilaksanakan dan harapannya untuk selanjutnya tetap diadakan kegiatankegiatan yang bermanfaat bagi masyarakat di RW 21 Nusukan Surakarta.

\section{SIMPULAN}

Kegiatan pengabdian pemanfaatan tanaman herbal dan pelatihan budidaya TOGA sebagai alternatif pengobatan mandiri di RW 21 Kelurahan Nusukan dapat berjalan lancar. Peserta mendapatkan informasi tentang

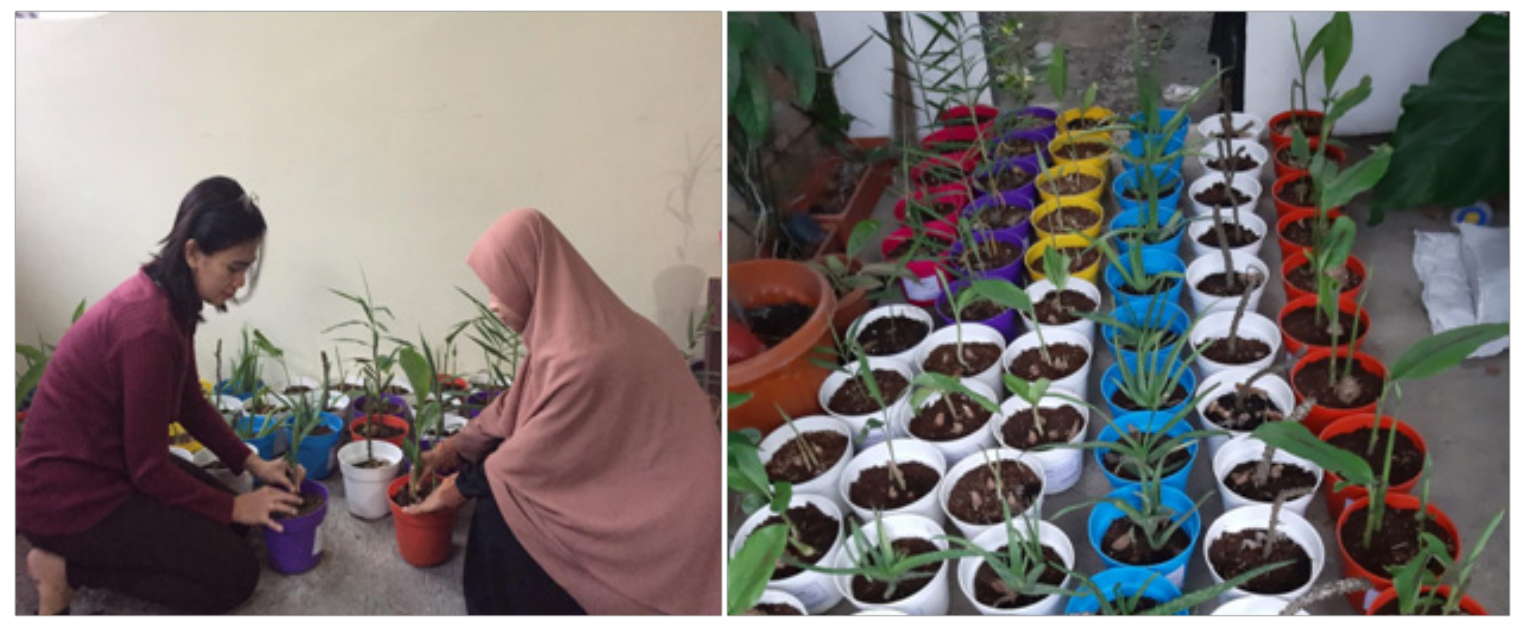

Gambar 2. Pelatihan Penanaman Bibit TOGA
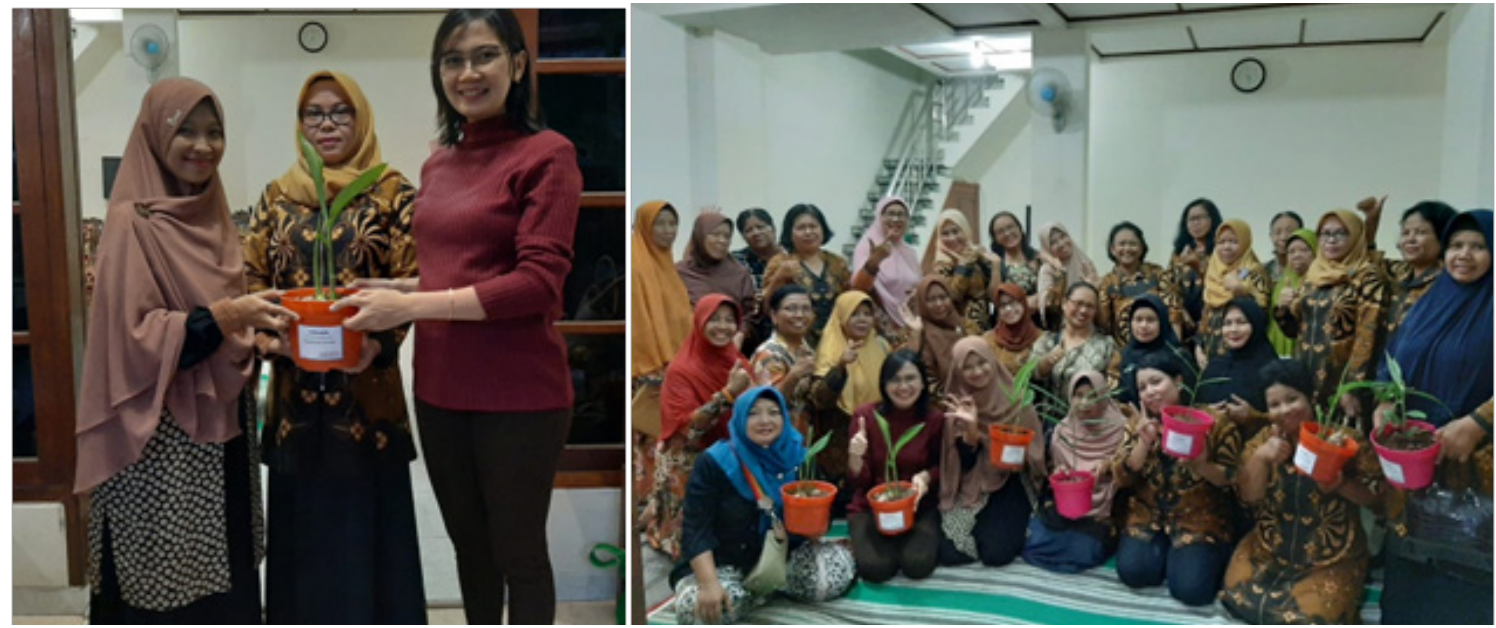

Gambar 3. Penyerahan Bibit TOGA kepada Warga RW 21 Nusukan 
penyakit artriris, memahami dan mengetahui jenis dan khasiat TOGA untuk pengobatan artritis, serta cara mengolah TOGA untuk pengobatan alternatif penyakit artritis. Peserta berkontribusi dalam pelatihan penanaman TOGA dengan menggunakan bibit TOGA yang sudah dibagikan.

\section{PERSANTUNAN}

Tim pengabdian masyarakat menyampaikan banyak terima kasih kepada LPPM Universitas
Setia Budi Surakarta yang telah membiayai program ini sehingga kegiatan pengabdian kepada masyarakat ini bisa berjalan dengan baik dan bermanfaat bagi perkembangan ilmu pengetahuan dan mampu berkontribusi kepada masyarakat. Kami juga mengucapkan terima kasih kepada mitra yang sudah berpartisipasi dalam kegiatan kali ini.

\section{REFERENSI}

Dalimartha S. (2006). Resep Tumbuhan Obat untuk Rheumatik. Jakarta: Penebar Swadaya. hlm 1-3, 10, $16,23,33,35$.

DiPiro JT et al. (2017). Pharmacotherapy Handbook. Tenth Edition. New York: McGraw-Hill.

Departemen Kesehatan. (2005). Pharmaceutical Care untuk Pasien Penyakit Diabetes Mellitus. Direktorat Bina Farmasi Komunitas dan Klinik Ditjen Bina Kefarmasian dan Alat Kesehatan Departemen Kesehatan. Jakarta.

Muhlisah, Fauziah. (2000). Taman Obat Keluarga (TOGA). Jakarta: Penebar Swadaya

Rahayu, M., et al. (2006). Pemanfaatan Tumbuhan Obat secara Tradisional oleh Masyarakat Lokal di Pulau Wawonii, Sulawesi Tenggara. Bogor: Bidang Botani, Pusat Penelitian Biologi, Lembaga Ilmu Pengetahuan Indonesia (LIPI).

Ridwan. (2007). Pemanfaatan Tanaman Obat Keluarga. Jakarta: Pusat Perbukuan Departemen Pertanian

Ronald. (2006). Obat-obatan Ramuan Tradisional. Bandung: Yrama Widya.

Savitri, Astrid. (2016). Tanaman Ajaib Basmi Penyakit dengan TOGA (Tanaman Obat Keluarga). Depok: Bibit Publisher.

Syafei, Candra. (2010). Permasalahan Penyakit Rematik dalam Sistem Pelayanan Kesehatan ( Bone and Joint Decade ). Proceeding Book Rhemumatology Update.

Tjay TH, K Rahardja. (2007). Obat-Obat Penting, Khasiat, Penggunaan dan Efek-efek Sampingnya. Edisi keenam. Jakarta: Penerbit PT. Elex Media Komputindo Kelompok Gramedia. hlm 324-325

Tukiman. (2004). Pemanfaatan Tanaman Obat Keluarga (TOGA) untuk Kesehatan Keluarga. Bagian Pendidikan Kesehatan dan Ilmu Perilaku Fakultas Kesehatan Masyarakat Universitas Sumatera Utara. USU: Digital Library.

World Health Organization. (2012). Promoting Rational Use of Medicines: Core Components. WHO. Geneva.

Yuliati, Agrina dan Misrawati. (2013). Gambaran Pengetahuan Keluarga tentang Pengobatan Rematik dengan Air Rebusan Jahe di Kelurahan Meranti Pandak Wilayah Kerja Puskesmas Rumbai. Riau: Program Studi Ilmu Keperawatan Universitas Riau.

Zakeri et al. (2011). Evaluating the effects of Ginger Extract on Knee Pain, Stiffness and Difficulty in Patients with Knee Osteoarthritis. Journal of Medicinal Research. Vol. 5 (15), pp. 3375-3379. 